\title{
MINERAL POTENTIAL MAPPING USING GEOGRAPHIC INFORMATION SYSTEMS (GIS) FOR GOLD MINERALIZATION IN WEST JAVA, INDONESIA
}

\author{
Seang Sirisokha*1, Lucas Donny Setijadji ${ }^{2}$, and I Wayan Warmada ${ }^{2}$ \\ ${ }^{1}$ Geo-resources and Geotechnical Engineering, Institute of Technology of Cambodia, Phnom Penh, Cambodia \\ ${ }^{2}$ Department of Geological Engineering, Gadjah Mada University, Yogyakarta, Indonesia
}

\begin{abstract}
Western Java is a part of the Sunda Banda magmatic belt. This belt is well known to be host for several gold deposits in Indonesia, the distribution of 107 Au occurrences in this area was examined in terms of spatial association with various geological phenomena. The goal of this project is to use GIS to conduct a weights of evidence (WofE) model for gold mineralization in West Java, Indonesia. A Geographic Information System (GIS) is a computer system for capturing, storing, querying, analyzing, and displaying geospatial data and weight of evidence method is one of the most important datadriven methods for mapping in GIS. The method is a probability based on technique for mapping mineral potential using the spatial distribution of known mineral occurrences. Therefore this method is very useful for gold potential mapping. There are six evidences maps such as NE-SW lineaments NW-SE Lineament, host rocks, heat sources, clay alteration and limonitic alteration, have been combined using a weights of evidence model to predict gold potential in West Java. The best predictive map generated by this method defines $21.62 \%\left(9902 \mathrm{~km}^{2}\right)$ of study area as favourable zones for gold mineralization further exploration work. It predicts correctly 74 (92.5\%) of the 80 model deposits and predicts correctly 26 $(96.35 \%)$ of the 27 validation deposits, has 6 main

${ }^{*}$ Corresponding author: S. SIRISOKHA, Geo-resources and Geotechnical Engineering, Institute of Technology of Cambodia. Russian Federation Blvd., P.O Box 86, Phnom Penh, Cambodia. E-mail: ssirisokha@yahoo.com
\end{abstract}

prospective target for future exploration are located in Bayah Dome, southern mountain, Honjie Igneous Complex and Bogor zone, Purwakarta. Bayah Dome is highest potential area for gold deposit like Gunung Pongor, Cikidang, Cirotan, Ciawitali, Cikotok destricts and other deposits. The potential area of Au occurrences in research area is associated with NE-SW and NW-SE structure/ lineaments, dominated surrounding the Tertiary intrusive rock unit and hosted in Miocene to Pleistocene lithology rock unit.

Keywords: GIS, Weight of evidence method, Mineral potential mapping, Bayah Dome, Bogor, West Java

\section{Introduction}

The gold mineralization in Western Java is typical of epithermal type deposit and hosted by Tertiary volcanic rocks. The gold deposits are extensively in the form of gold bearing quartz veins that classified as epithermal low sulphidation and high sulphidation (Marcoux and Milési, 1994). Many epithermal-style alterations and mineralization are associated with this volcanoclastic and intrusive rocks, including epithermal gold deposits and few prospect areas for possible mineralization of porphyry systems.

This research is carried out to create gold potential map by using weight of evidence method in (GIS), for the benefits of future ex- 
ploration of gold in the study area. The study area is located in the western part of Java Island in Indonesia, within longitude $105-109^{\circ} \mathrm{E}$ and latitude $6-8^{\circ} \mathrm{S}$ (Figure $1 \mathrm{la}$ ).

\section{Teoretical background}

\section{Regional geology}

Java Island represents part of Sunda-Banda arc due to the subduction of the northward-moving Indian-Australian Plate beneath the Eurasian Plate, which consists of a belt of active calcalkaline volcanos (Claproth, 1989). These features are built upon older volcanic and volcanoclastic rocks that are intercalated with Paleogene and Neogene sediments and intruded by small plutonic masses of composition similar to the volcanic.

Physiographically, the Southern Mountains of West Java region belongs to the Sunda-Banda magmatic arc (Figure 1 $1 \mathrm{p}$ ). This arc has been formed since Early Tertiary and still active until now. The area is a part of southern slope regional uplift (van Bemmelen, 1949). The main structural features of Java, there are three main strike slip-faults found in Java. In western Java has a still active NE-SW Cimandiri fault crosscut the whole of West Java. The second strike slip-fault named the Citandui fault, occurs in western Java and trends NW-SE. The third system occurs in central Java, namely central Java fault as a NE-SW left-lateral strike-slip fault which crosscut the whole island (Setijadji et al., 2006).

\section{Mineral deposits}

Mineral occurrences in Java are located in the physiographic area known as the Southern Mountains. This physiographic area contains the most extensive exposures of Tertiary magmatic rocks in the island that range in age from Eocene to Upper Miocene (Setijadji et al., 2006; Smyth et al., 2005; Soeria-Atmadja et al., 1994), this physiographic area is considered the most prospective region for metallic mineral deposits. Western Java hosts number of epithermal deposits of precious metals associated with the calc-alkaline volcanism, still active in the area. Its major metallogenic event during the Miocene and the Pliocene are located in the Bayah Dome, a Tertiary-Quaternary volcanic structure at western of Java. Gold ore of West Java deposited in many districts (Figure 2 a).

\section{Application of weight of evidence in mineral potential mapping}

The steps in applying weight of evidence (Bonham-Carter, 1994) are follow:

1. Choose a series of maps that are likely to be evidence for predicting mineral deposit. A particular deposit type and associated conceptual deposit model should be used to guide the selection process.

2. For each map, assumed to be multi-class (categorical or higher measurement levels), determine the optimum reclassification scheme to binary form, maximizing the spatial association between the map and the deposit point. Weight of evidence calculation can be used for this optimization process.

3. Check for pairwise Conditional Independence, CI between the binary maps. Delete problem maps, or combine binary maps to reduce effect of $\mathrm{CI}$.

4. Combine the binary maps with weights determined in step 2. This can be carried out either with a modeling language internal to GIS, or with external modeling program. Make new maps showing posterior probability. Optionally, calculate the effects of uncertainty in the weight, and uncertainty due to missing information, and produce an uncertainty map.

\section{Research methodology}

\section{Research preparation}

The first steps, red carefully about the basic theory and previous study related to the gold deposit in West Java and also collect datas to make gold potential map like geological map, mineral deposit, ASTER GDEM and Landsat Thematic Mapper (TM). 

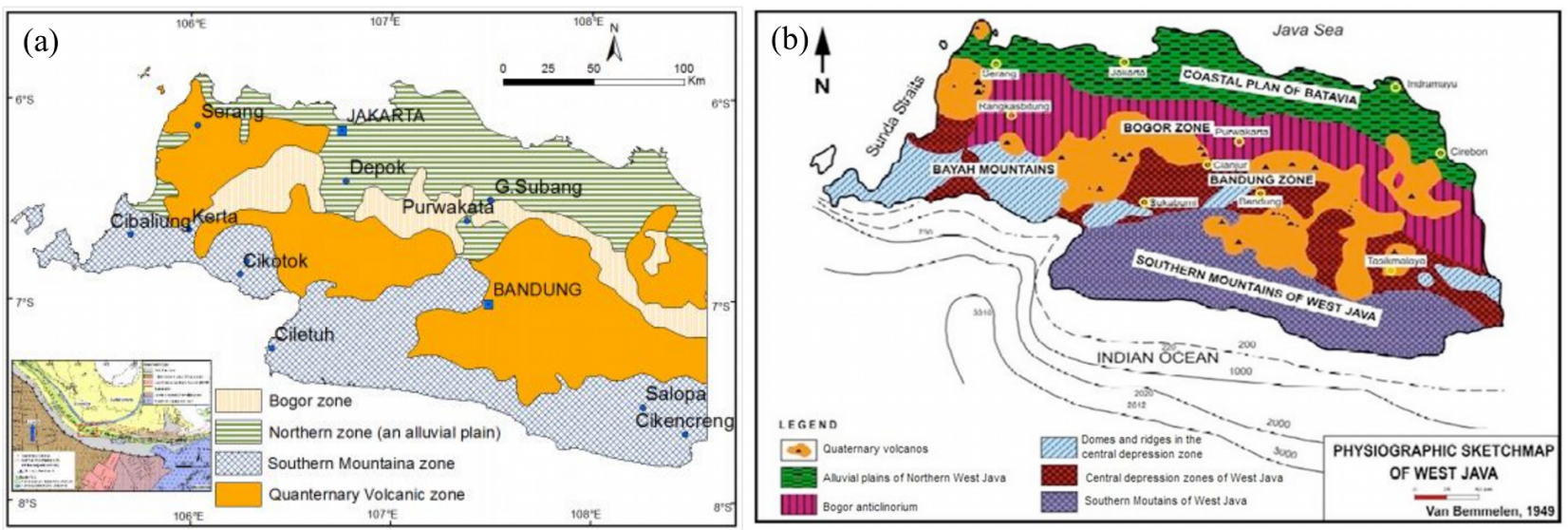

Figure 1: (a) The locality of research area in West Java, Indonesia (modified from van Bemmelen, 1949). (b) Physiographic map of West Java (after van Bemmelen, 1949 and Martodjojo, 1984 in Suparka et al., 2007).
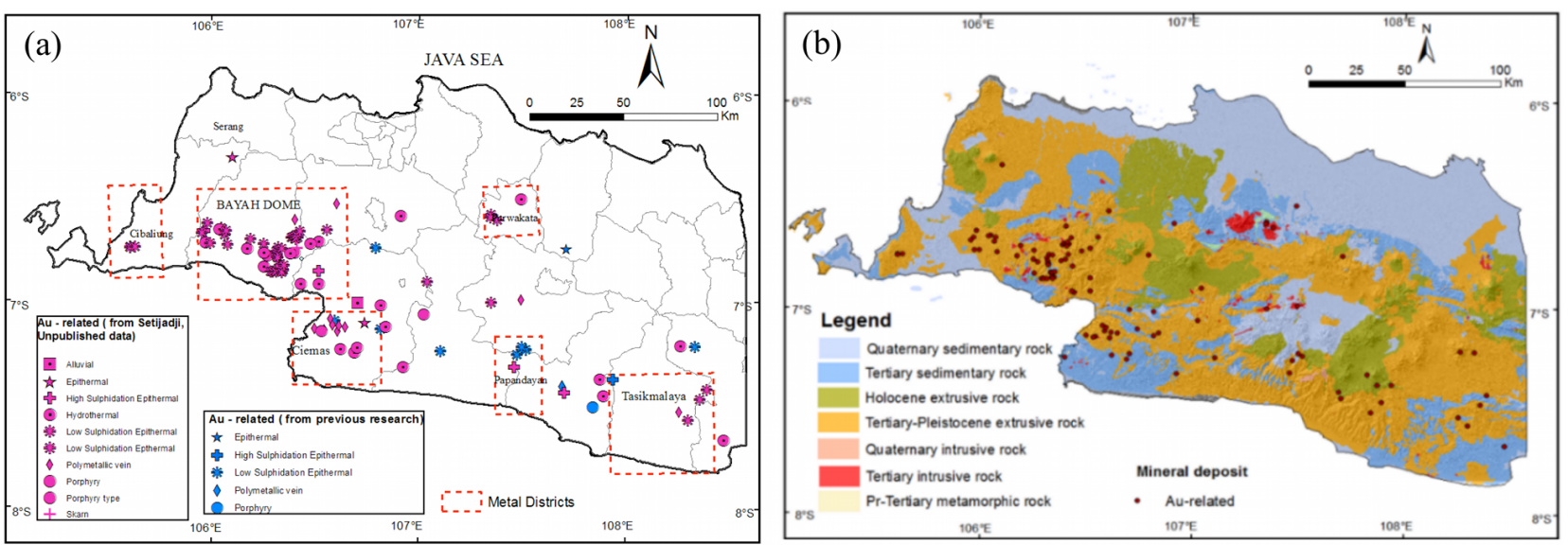

Figure 2: (a) Location of gold deposits in West Java (Setijadji, Unpublished data and from previous research Nurcahyo et al., 2012; Syafrizal et al., 2011; Subandrio et al., 2010; Suparka et al., 2007; Utoyo, 2007 and Ismayanto et al., 2005). (b) Lithology map of the study area (lithology map is derived from digital version of many geology maps sheets, scale 1:100,000 by Geology Agency of Indonesia, Unpublished data). 


\section{Spatial data processing and analysis}

Mineral deposit database: The study area contains 134 metallic deposits and industrial mineral occurrences of various sizes, but not all of metallic deposits are related to $\mathrm{Au} \mathrm{oc-}$ currences. There are 107 metallic deposits occurrences containing $\mathrm{Au}$ (based on attributed table of metallic deposits layer) which are used in this study (Figure 2b).

Lithology: Lithology map is created from geological map, collect as secondary data that digital geological map is derived from digital version of several 1:100,000 scale geological maps (Figure 2b). So, based on the characteristics of mineral deposits in study areas, all of Tertiary to Pleistocene lithology unit is selected for host rocks (Figure 3a) and Tertiary intrusive rocks are considered as heat sources (Figure $3 \mathrm{~b}$ ).

Geological Structure: In order to identify lineaments from the DEM, four shaded relief images were generated. The first step is the production of four separate shaded relief images with light sources coming from four different directions. The shaded relief image created had a solar azimuth (sun angle) of $0^{\circ}, 45^{\circ}, 90^{\circ}, 315^{\circ}$ (Figure $4 \mathrm{a}-\mathrm{d}$ ) and a solar elevation of $45^{\circ}$. The second step is to combine four shaded relief image to produce one shaded relief image (Figure $5 \mathrm{~b}$ ). The last step, the lineament is digitized using manual extraction techniques from one shade relief (Figure 5b). The orientation of the lineament is analyzed by rose diagram. In this study, the lineament dived into two direction NE-SW and NW-SE because structure in study area are mostly have these direction (Figure 5 ) .

Hydrothermal alteration: Two hydrothermal alteration maps as clay and limonitic alteration are derived from Landsat $5 \mathrm{TM}$. The first step in this methodology is to use the software defoliant technique to enhance the spectral response of each alteration mineral (clay and iron oxide alteration zone). Clay alteration is generated using band ratio 4:3 and 5:7 and limonitic alteration by using band ratio $3: 1$ and $4: 3$. Band ratio $4 / 3$ refers to vegetation index, band ratio
$5 / 7$ refers to clay mineral index and band ratio $3 / 1$ refers to limonitic index.

Landsat $5 \mathrm{TM}$ is use to generate the clay and limonitic alteration. They use software defoliant method to extract the clay and limonitic alteration by using divided tool (spatial analysis tools $>>$ math $>>$ divided) and principal components (spatial analysis tools $>>$ multivariate $>>$ principal components) tool in GIS. The result of clay and limonitic alteration show in Figures 6 a and 6 b.

\section{Data analysis}

The geological evidence features that are used as predictors of gold potential in the study area consist of 6 evidence maps as follows: NESW trending lineaments, NW-SE trending lineaments, host rocks, heat sources, clay alteration and limonitic alteration. Mineral deposits are split into 2 subsets. First subset of 80 (75\%) of the total 107 known mineral deposit occurrences are used to generate the probabilistic models (called as training data). The other subset of 27 ( $25 \%$ called as validation data) of 107 known mineral deposit occurrences are used to validate the probabilistic models (called as validation data). The mineral deposits that comprise the validation subset were chosen randomly. A pixel size of $30 \times 30 \mathrm{~m}$ was used in the probabilistic mapping of Au mineralization potential. All binary maps need to convert into raster with pixel size $30 \times 30 \mathrm{~m}$ because Remote sensing data in here is $30 \times 30 \mathrm{~m}$.

For select the cutoff distance was considered three criteria, the Studentized C, Contrast (C) and mineral occurrences. The Studentized $C$ is the first parameter for considering the cut off distance. And Contrast is the seconded parameter. Both of them need to be correlated with the percentage of mineral occurrence. The Studentized value of $C$ is used to define the optimum cutoff. Ideally it is nice to see a Studentized value larger than 1.5 or even 2 .

\section{Calculating weights of evidence of NE-SW trending lineaments}

NE-SW lineaments are selected from lineaments in figure 10. NE-SW lineaments are 

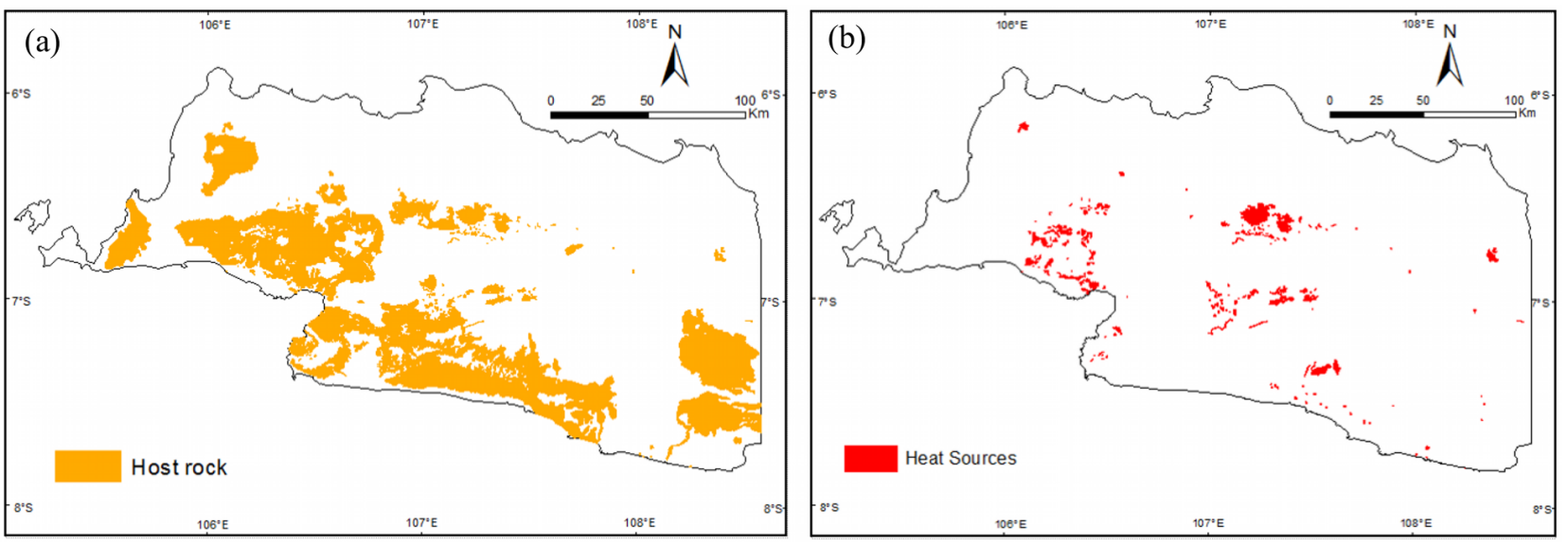

Figure 3: (a) Tertiary-Pleistocene host rock. (b) Tertiary intrusive rock (heat source).
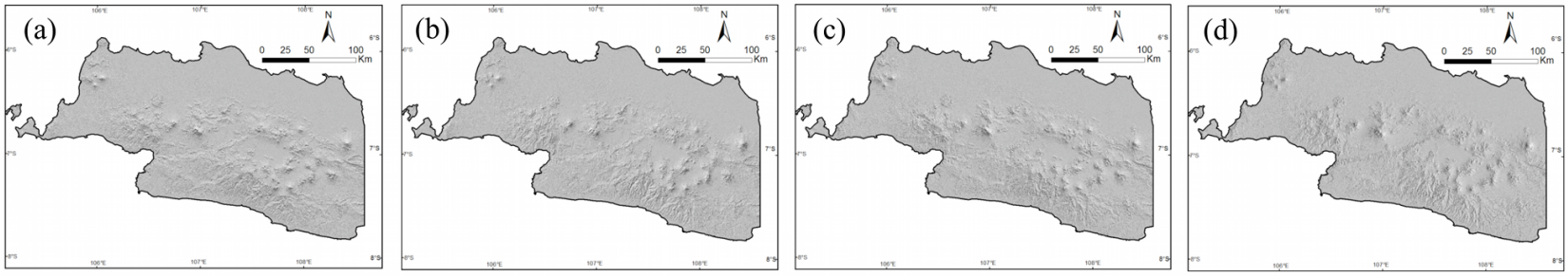

Figure 4: Four shaded relief images derived from DEM with different illumination directions (sun azimuth) of $0^{\circ}, 45^{\circ}, 90^{\circ}$, and $315^{\circ}$, with a solar elevation of $45^{\circ}$.
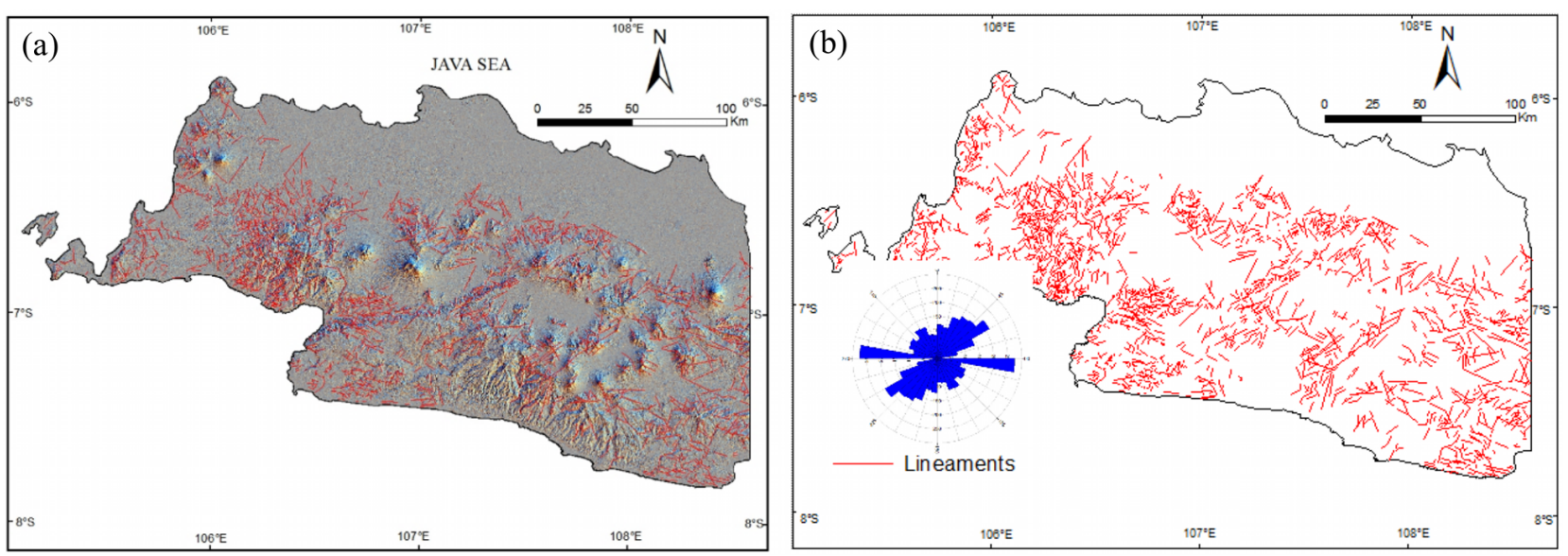

Figure 5: (a) The Combined shaded relief DEM image created by combining several shaded relief images with different illumination. (b) Lineaments map, interpreted from shaded relief DEM image 

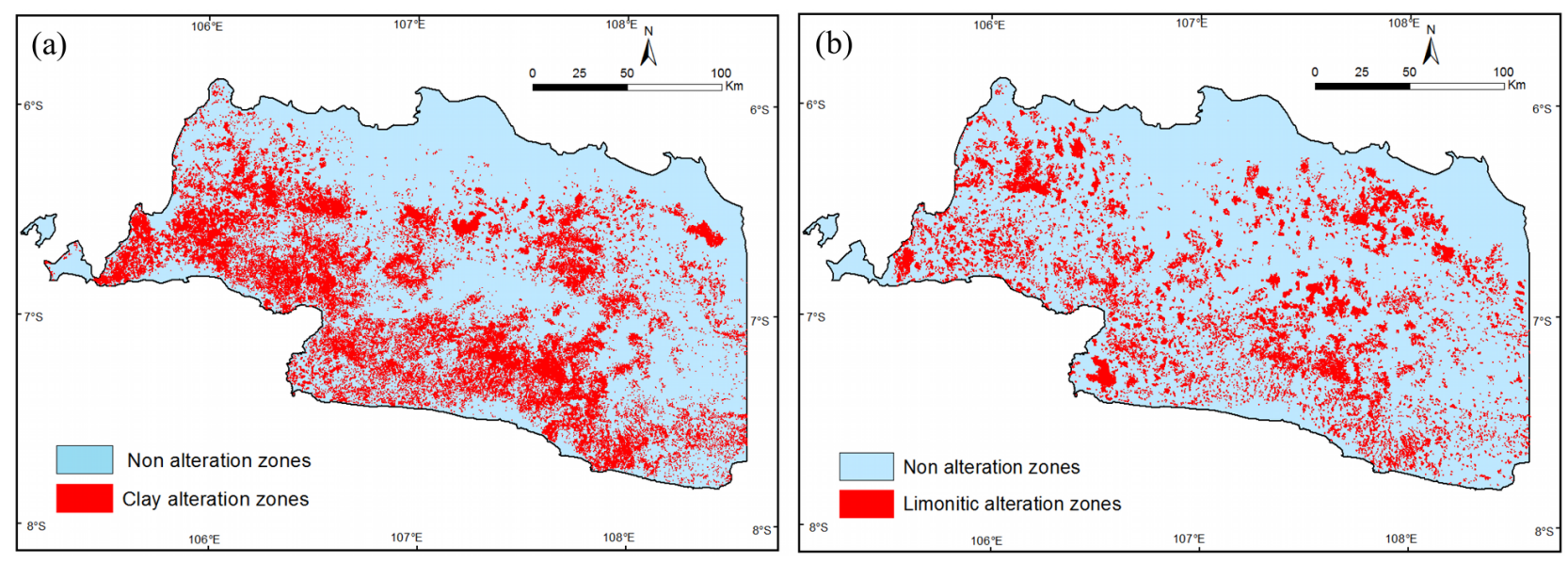

Figure 6: (a) Clay alteration map using the software defoliant technique. (b) Limonitic alteration map using the software defoliant technique.

buffered at 250 to $6000 \mathrm{~m}$, and crossed with the raster mineral occurrence point map to estimate weights of evidence of domain (Table 1). The Studentized C (5.69) is highest at $2000 \mathrm{~m}$ and contrast is highest at $5000 \mathrm{~m}$. The optimum buffer is defined at $2000 \mathrm{~m}$. The resulting buffered lineament domain cover $18257 \mathrm{~km}^{2}$ $(39.86 \%)$ of area, $59(73.75 \%)$ out of 80 mineral occurrences are present in this distance (Figures $7 \mathrm{a}-\mathrm{b})$. The weight of evidence analysis reveals a strong correlation between the lineament domain and mineral occurrences and buffer at optimum distances for each evidence maps as shown in Figure 8 .

\section{Test of conditional independence}

As a result in the Table 2 indicate that the value of $\chi^{2}$ are smaller than the 5.4 , thus the hypothesis for conditional independence is obeyed or accepted at this probability level (Alder and Roessler, 1972), except the pair NE-SW and Clay, NE-SW and limonitic, and clay and limonitic are bigger than 5.4. Thus, three binary predictor patterns are not statistically significant. Based on the critical $\chi^{2}$ used, they can still be combined to conduct map mineral potential but the statistical validity of the resulting posterior probability map must be examined by applying an overall test of conditional independence (Carranza, 2002).
Table 2: Calculated $\left(\chi^{2}\right)$ values for testing conditional independence between all pairs of binary maps with respect to gold occurrences.

\begin{tabular}{|l|l|l|l|l|r|}
\hline $\begin{array}{l}\text { Evidence } \\
\text { maps }\end{array}$ & Heat & $\begin{array}{l}\text { NE- } \\
\text { SW }\end{array}$ & $\begin{array}{l}\text { NW- } \\
\text { SE }\end{array}$ & Clay & Limonitic \\
\hline Host & 2.882 & 0.214 & 2.391 & 0.254 & 0.192 \\
\hline Heat & & 0.446 & 1.263 & 0.486 & 1.325 \\
\hline NE-SW & & & 0.632 & $\mathbf{8 . 8 3 2}$ & $\mathbf{6 . 5 8 4}$ \\
\hline NW-SE & & & & 0.369 & 0.944 \\
\hline Clay & & & & & $\mathbf{1 1 . 6 8 4}$ \\
\hline
\end{tabular}

\section{Results and discussion}

\section{Probabilistic mapping of gold minerals poten- tial}

The values and binary predictor maps were used to generate regional scale posterior probability maps of the area. Initially, a probability map is generated using the 6 maps and 4 maps (exclusive clay and limonitic alteration) with the values from Table 11). The binary pattern of clay alteration and limonitic alteration show the chi-square more than 5.4 (with 1 degree of freedom and a probability level of $98 \%$, table $\chi^{2}$ value is 5.4), so clay alteration and limonitic alteration is not strong relationship with $\mathrm{Au}$ occurrences (Table 2). The prior probability 

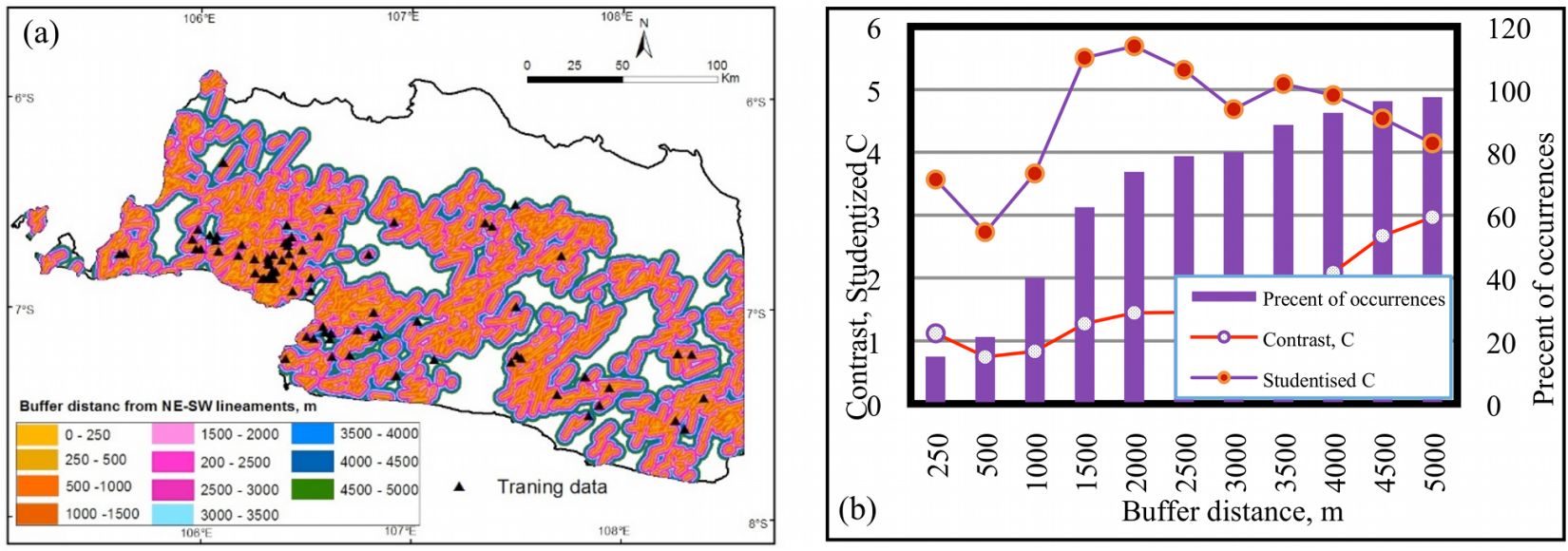

Figure 7: (a) Buffer distance s to the NE-SW lineaments. (b) Graph showing the studentized contrast, $\mathrm{C}$ and percent of Au occurrences related with buffer at distance for NE-SW trending.

Table 1: An appropriated the evidence maps base on conditionally independent and statistically significant contrasts for predict the Au occurrences in research area (Figure 8).

\begin{tabular}{|l|r|c|c|c|c|c|c|c|c|c|}
\hline Binary predictor & $\begin{array}{c}\text { Distance } \\
(\mathbf{m})\end{array}$ & $\mathbf{N}\{\mathbf{B}\}$ & $\mathbf{N}\{\mathbf{B} \cap \mathbf{D}\}$ & $\mathbf{W}+$ & $\mathbf{s}(\mathbf{W}+)$ & $\mathbf{W}-$ & $\mathbf{s}(\mathbf{W}-\mathbf{)}$ & $\mathbf{C}$ & $\mathbf{s}(\mathbf{C})$ & $\mathbf{C} / \mathbf{s}(\mathbf{C})$ \\
\hline $\begin{array}{l}\text { NE-SW } \\
\text { lineaments }\end{array}$ & 2000 & 18257 & 59 & 0.617 & 0.13 & -0.83 & 0.218 & 1.447 & 0.254 & 5.69 \\
\hline $\begin{array}{l}\text { NW-SE } \\
\text { lineaments }\end{array}$ & 1000 & 8302 & 36 & 0.912 & 0.167 & -0.398 & 0.151 & 1.31 & 0.225 & 5.822 \\
\hline Host Rock & 0 & 7130 & 74 & 1.791 & 0.117 & -2.423 & 0.408 & 4.213 & 0.425 & 9.922 \\
\hline Heat Sources & 4500 & 7792 & 39 & 1.056 & 0.161 & -0.483 & 0.156 & 1.539 & 0.224 & 6.868 \\
\hline Clay alteration & 50 & 7222 & 35 & 1.024 & 1.169 & -0.404 & 0.149 & 1.428 & 0.226 & 6.326 \\
\hline $\begin{array}{l}\text { Limonitic } \\
\text { alteration }\end{array}$ & 150 & 8504 & 38 & 0.942 & 0.163 & -0.44 & 0.154 & 1.382 & 0.224 & 6.163 \\
\hline
\end{tabular}



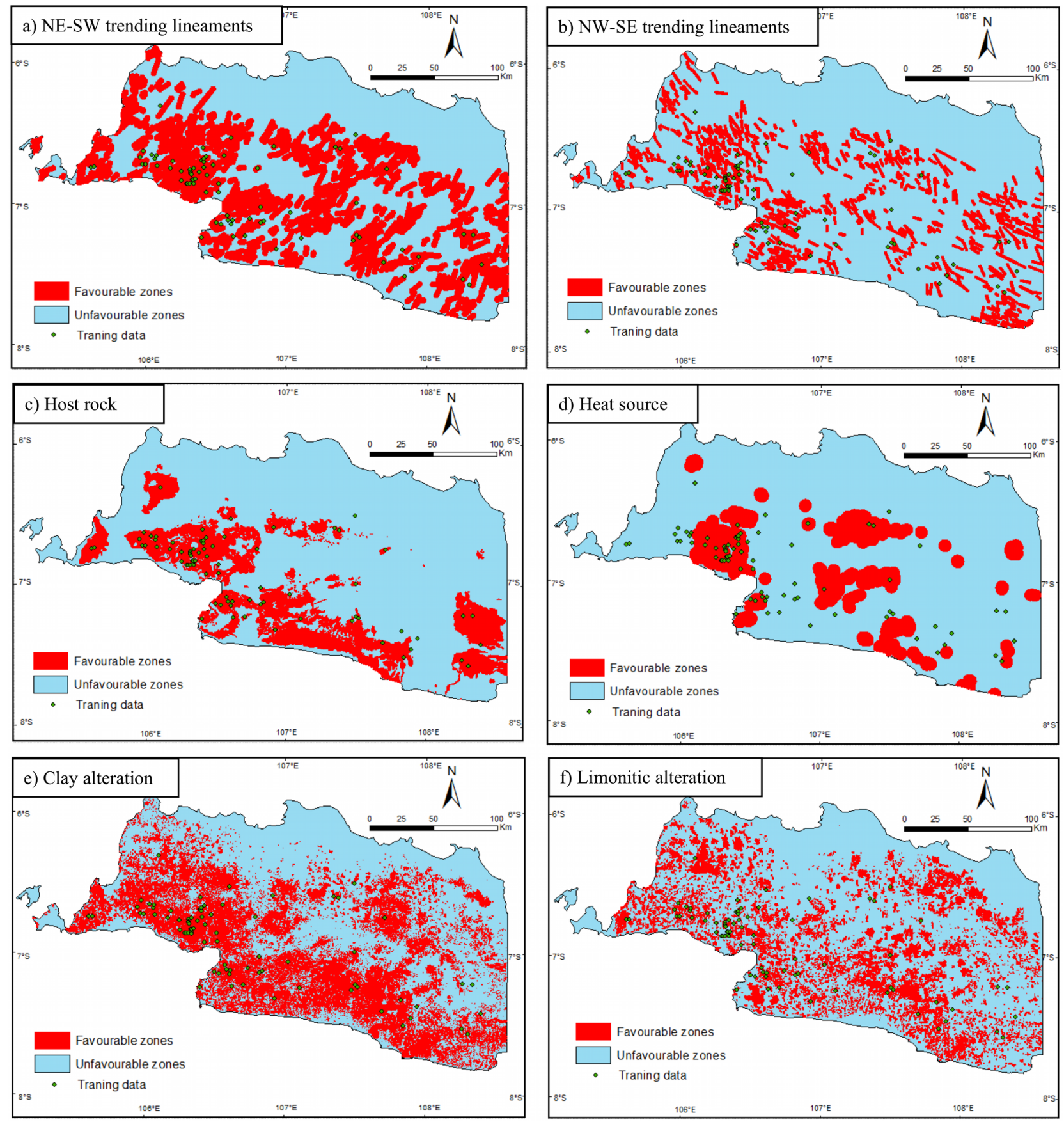

Figure 8: Binary predictor patterns of all evidence maps, buffered at distances with optimal spatial associations, red color are favorable zone for prospect Au occurrences. a) NE-SW Lineaments, b) NW-SE Lineaments, c) Host rock, d) Heat sources, e) Clay alteration, and f) Limonitic alteration. 
Table 3: Inventory of Au occurrences in zones of different posterior based on Figure 9 a, which are derived from all of predictor patterns present in Table 1 , and based on resulting from exclusion of clay and limonitic alteration binary predictor patterns.

\begin{tabular}{|l|c|c|c|c|c|}
\hline \multirow{2}{*}{ Au Potential } & \multicolumn{5}{|c|}{$\begin{array}{c}\text { Posterior probability map } \\
\text { based on Figure 9a }\end{array}$} \\
\cline { 2 - 6 } & $\begin{array}{c}\% \\
\text { Area }\end{array}$ & \multicolumn{2}{|c|}{$\begin{array}{c}\text { Model } \\
\text { deposits }\end{array}$} & \multicolumn{2}{|c|}{$\begin{array}{c}\text { Validation } \\
\text { deposits }\end{array}$} \\
\hline & & No & $\%$ & No & $\%$ \\
\hline $\begin{array}{l}\text { Unfavorable } \\
\text { zones }\end{array}$ & 83.73 & 10 & 12.5 & 1 & 3.7 \\
\hline $\begin{array}{l}\text { Favorable } \\
\text { zones }\end{array}$ & 16.27 & 70 & 87.5 & 26 & 96.3 \\
\hline Total & & 80 & 100 & 27 & 100 \\
\hline
\end{tabular}

$P\{B\}=80 / 45803=0.0017466$ and $\log e\{D\}=$ $\log e(P\{B\} /(1-P\{B\}))=-6.3483$.

According to the value of posterior probabilities, the favorability map of Au potential is separated into favourable and unfavourable zones. A ratio less than one $\left(P_{\text {posterior }} / P_{\text {prior }}\right.$ $=0.0017466)$ are indicated as unfavorable zone and a ratio greater than one are indicated as favorable zone. The favorability maps of Au minerals potential are shown in Figures $9 \mathrm{a}-\mathrm{b}$.

\section{Model validation}

The posterior probability map of gold occurrence in Figure 99 indicates that about $16.27 \%$ is favorable zones and $83.73 \%$ is unfavorable zones (Table 3). Due to gold occurrences map reveals that $10(12.5 \%)$ of 80 occurrences gold deposits are presented in unfavorable zones and $70(87.5 \%)$ are present in favorable zones of the model deposits. Moreover, there have only one gold validation deposits are located in unfavorable zone while other 26 gold deposits are located in favorable zone; it means the statistical validity is acceptable $(96.3 \%$ of validation deposits).

Based on the Figure $9 \mathrm{p}$ clarified that about $21.62 \%$ of study areas is favorable zone and $78.38 \%$ is unfavorable zone. For gold probability, there have only $74(92.5 \%)$ out of 80 gold
Table 4: Inventory of Au occurrences in zones of different posterior based on resulting from exclusion of clay and limonitic alteration binary predictor patterns (Figure $9 \mathrm{~b}$ ).

\begin{tabular}{|l|c|c|c|c|c|}
\hline \multirow{2}{*}{ Au Potential } & \multicolumn{5}{|c|}{$\begin{array}{c}\text { Posterior probability map } \\
\text { based on Figure 9b }\end{array}$} \\
\cline { 2 - 6 } & $\begin{array}{c}\% \\
\text { Area }\end{array}$ & \multicolumn{2}{|c|}{$\begin{array}{c}\text { Model } \\
\text { deposits }\end{array}$} & \multicolumn{2}{|c|}{$\begin{array}{c}\text { Validation } \\
\text { deposits }\end{array}$} \\
\hline & & No & $\%$ & No & $\%$ \\
\hline $\begin{array}{l}\text { Unfavorable } \\
\text { zones }\end{array}$ & 78.38 & 6 & 7.5 & 1 & 3.7 \\
\hline $\begin{array}{l}\text { Favorable } \\
\text { zones }\end{array}$ & 21.62 & 74 & 92.5 & 26 & 96.3 \\
\hline Total & 80 & 80 & 100 & 27 & 100 \\
\hline
\end{tabular}

deposits fall within favorable zones and there are $26(96.3 \%)$ among of 27 gold validation deposits (Table 4). According to model validation, the statistical validity is acceptable. Depend on the conditionally independent, high statistically significant contrasts validation model; the posterior probability of gold potential map (Figure 9p) has higher successful rate then the gold potential map (Figure 9a).

\section{Overall test}

The posterior probability map as shown in Figure $9 \mathrm{~b}$ was analyzed by an overall test for conditional independence, the result of predicted number of deposits is 91 (formula of overall test, Table 5). The observed number of mineral deposit is 80 , therefore the predicted number of deposit is higher the observed number of mineral $11(13.5 \%)$. According to the condition of overall test, this map was accepted as statistically valid.

\section{Gold potential map}

Based on the ratio of posterior probability to prior probability $\left(P_{\text {posterior }} / P_{\text {prior }}\right)$ (Figure $\left.9 \mathrm{p}\right)$, the resulting predictive map is classified into three categories: low prospectively, moderate prospectively and high prospectively. Thus, if the ratio is less than $1\left(P_{\text {posterior }} / P_{\text {prior }}<1\right)$ then potential is unfavorable zones, if the ratio range 

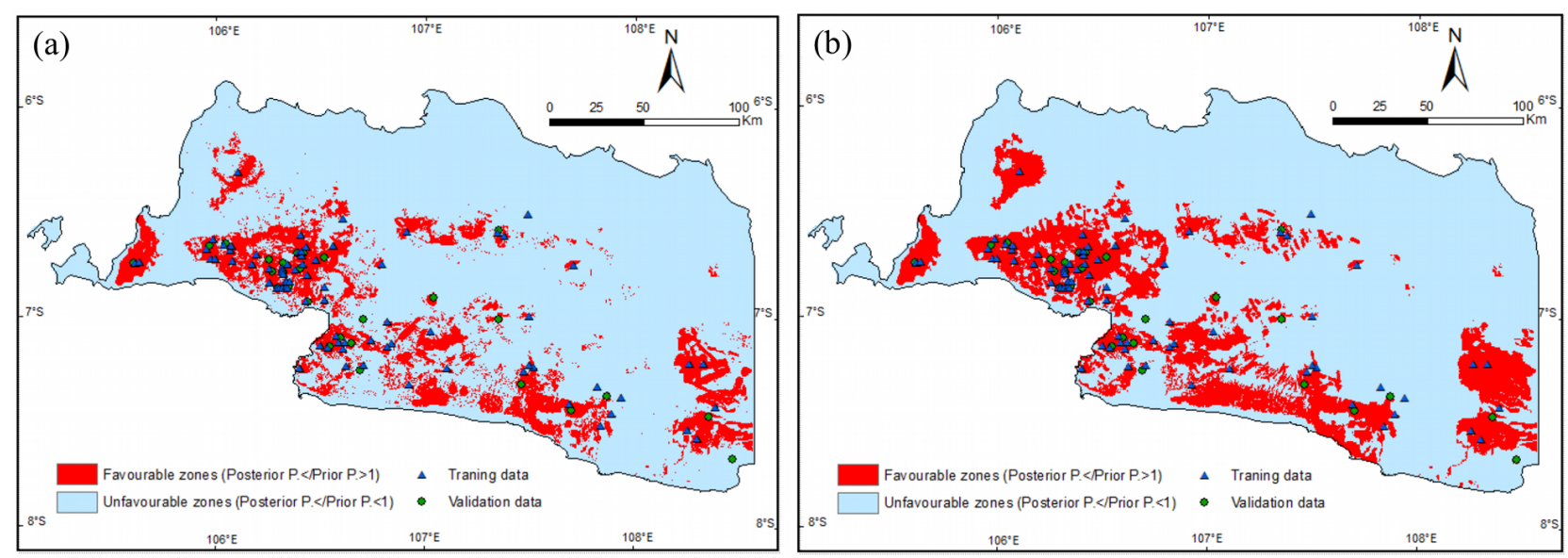

Figure 9: (a) Posterior probability map of Au in research area, derived from all predictor patterns present in Table 1. (b) Posterior probability map of Au in research area, resulting from exclusion of clay and limonitic alteration binary predictor patterns.

Table 5: Summarized of overall test conditional independence in posterior probability map shown in Figure 11 .

\begin{tabular}{|c|c|c|}
\hline $\begin{array}{c}\text { Probability } \\
\text { values in map }\end{array}$ & Area & $\begin{array}{c}\text { Predicted number } \\
\text { of deposit }\end{array}$ \\
\hline 0.000028036 & 20335 & 0.57 \\
\hline 0.000051839 & 14104 & 0.73 \\
\hline 0.0001709 & 4710 & 0.80 \\
\hline 0.001937 & 1528 & 2.96 \\
\hline 0.005712 & 2118 & 12.10 \\
\hline 0.01024 & 1775 & 18.18 \\
\hline 0.04502 & 1233 & 55.51 \\
\hline TOTAL & $\mathbf{4 5 8 0 3}$ & $\mathbf{9 0 . 8 5}$ \\
\hline
\end{tabular}

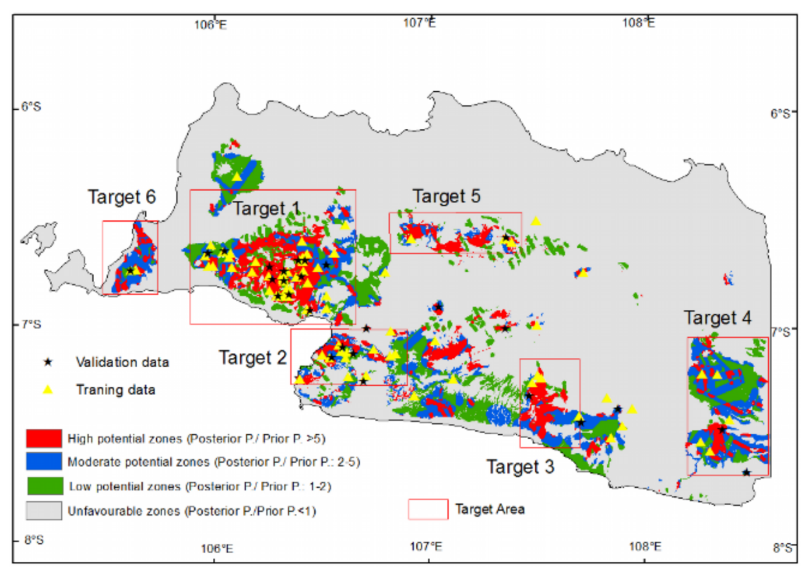

Figure 10: Predictive map of gold in West Java and generate prospective target area for $\mathrm{Au}$.

from $1-2$ is classified as low potential, if the ratio range from $2-5$ is classified as moderate and if the ratio is greater than 5 is classified as high (Figure 10).

From the result of the Au prospectively map in Figure 10 indicated that about $3649 \mathrm{~km}^{2}$ $(7.96 \%)$ of research area is low potential, 2844.75 $\mathrm{km}^{2}(6.21 \%)$ is moderate potential and 2907 $(6.35 \%)$ is high potential zones. There have 6 prospective targets for further investigation are shown in Figure 10, the biggest prospective gold deposits are located in Bayah dome (Taget 1) and other small potential are located in Ciemas (Target 2), Garut (Target 3), Tasikmalaya (target 4) Bogor zone, Cianjur districts 
and Purwakarta (Target 5), Pandeglang (Honjie Igneous Complex, target 6). In contrast, there have no potential area of gold deposit in Coastal Plan of Batavia.

Prospective Target 1: The Bayah Dome (target 1) in the western part of the Sunda-Banda arc is high potential zones by low-sulphidation epithermal vein sytems including Gunung Pongor, Cikidang, Cirotan, Ciawitali Cikotok destricts and aother deposits. The area of highest potential are dominated with major NE-SW and NW-SE lineaments, the intersection zones between lineaments, and also characterized by minor N-S lineament (Figure 11/1), which could provide fluid pathways for mineralizing fluids at upper crustal levels and facilitate the movement of deep-crustal fluids to higher crustal levels, as well as provide structural traps and the appropriate physio-chemical conditions conductive to ore deposition. Lithologies permissive high potential is dominaied by the intrusive intermediate, extrusive intermediate lava/poymict/pyroclastic, sandstone, breccias and claystone-shale, which the ranges of age are between Pleistocene-Eocene.

Prospective Target 2: The prospective target 2 is located in southern part of West Java; the potential zones are dominated in Ciemas destrict. This region is covering the Cigaru local mine and there are several prospect areas such as Cimanggu, Cijiwa, Cilubang, Cipaku, and Citugu and some exploration works have been conducted by Hunamas and Mispec (Syafrizal et al., 2011; Basuki et al., 2012). The potential zones are located and parallel to major NWSE lineaments (Figure $11 \mathrm{~b}$ ). The lineaments are not dense like target 1 . The lithologies associated with the potential zones are including Upper Miocene to Miocene intrusive intermediates, Lower Miocene extrusive intermediate lava, Miocene-Pliocene clastic limestone, and Eocene sandstones.

Prospective Target 3: The prospective target 3 is located Garut Renency, about $75 \mathrm{~km}$ to the southeast of the major city of Bandung. These area targets have many gold deposits like $\mathrm{Ci}$ - julang, Arinem, Pakenjeng, Cihar, Cibaliung, Bunikasih and Tutugan Area. The potential zones are associated with NE-SW and NWSE lineament (Figure 11k) and the litologies is hosted by extrusive intermediate pyroclastic, extrusive felsic lava, intrusive intermediate and the ranges of age from Miocene-Upper Pleistocene.

Prospective Target 4, 5, and 6: The prospective target 4, 5, 6 are located in Tasikmalaya, Bogor, Cianjur, Purwakarta and Pandeglang (Honjie Igneous Complex, target 6). The potential zones are mostly associated with NESW and NW-SE lineaments (Figures $11 \mathrm{~d}-\mathrm{f}$ ). There are many gold mineraliation such salopa, Cineam, Cipatu (Tasikmalaya), Cibaliung, Cicurug, Cibeber (Honjie Igneous Complex), Awilega Gunung Parang (Purwakarta), Gunung Pancar (Bogor). The litologies is hosted by Intrusive intermediate, claystone-shale, extrusive intermediate polymict, sandstone, extrusive felsic lava, intrusive felsic (Lower MiocenePleistocene).

\section{Weight of evidence approach}

Weight of evidence method is practically suited for modeling the spatial correlations between geological features and known mineral occurrences which are important for mapping mineral potential. The results of the gold potential map are getting from executing the different six evidences maps such as Host rock (TertiaryPleistocene lithology unit, heat source (Tertiary intrusive rock unit), NE-SW lineaments, NWSE lineaments, clay alteration and limonitic alteration.

All of evidence maps were created buffer at distance and optimum cutoff distance are summarized in Table 2 . The positive weight $(\mathrm{W}+)$ of host rock evidence map and ratio of percentage of Au occurrences to percentage of total area is greater than other evidence maps, following by Heat source, clay alteration, NW-SE lineaments limonitic alteration, and NE-SW lineaments evidence maps (Figure 12).

The host rock evidence map generates from lithology map is very important control on emplacement of Au occurrences indicated to be the 

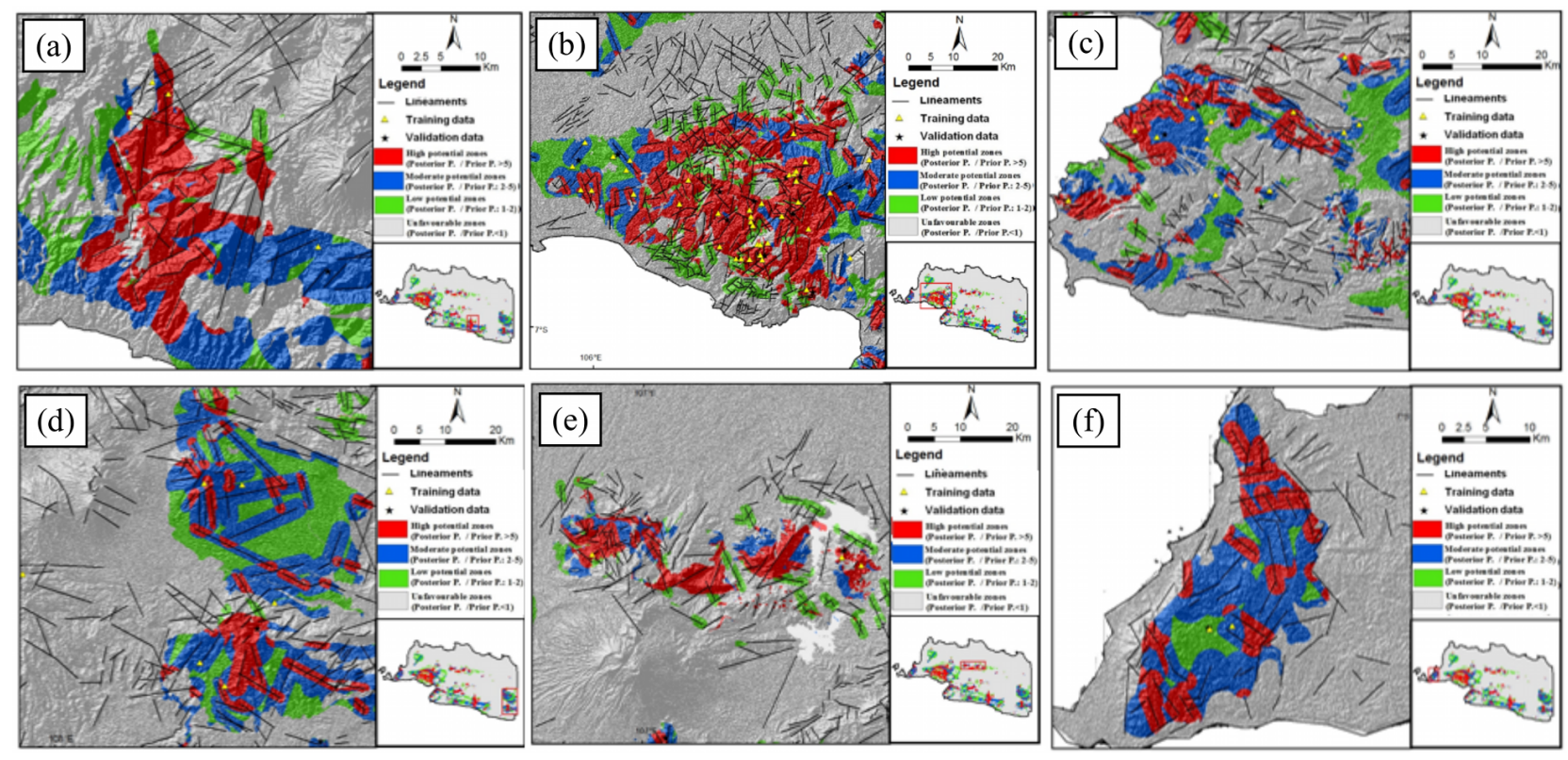

Figure 11: Mineral potential map superimposed on shaded of topography, overlain by lineaments and Au occurrences in Target 1, 2, 3, 4, 5 and 6.

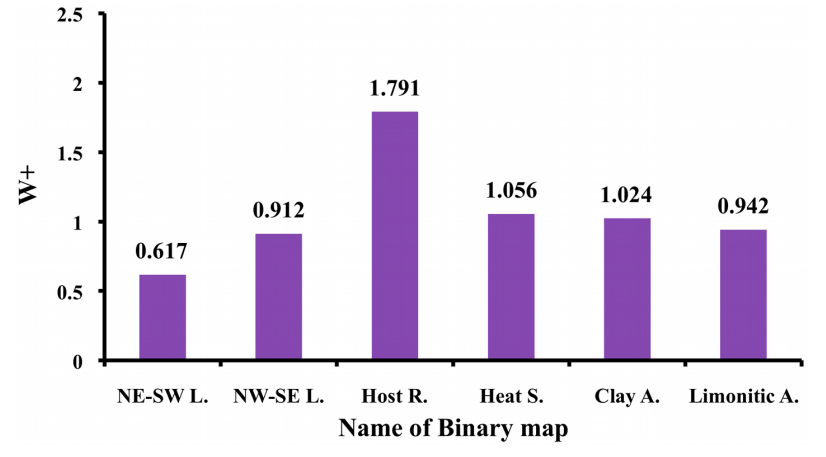

Figure 12: Graph showing the positive weight $(\mathrm{W}+)$ of all evidence maps which used to predict Au occurrences map.

strongest spatial predictor than other. The hillshade images derived from ASTER GDEM was useful to extract lineaments feature and NE-SW lineaments is important one.

The test for conditional independence shows that chi-square value for the pair NESW and Clay, NESW and Limonitic, and Clay and Limonitic are statistically significant. They do not reject the binary maps of these geological features in the analysis because gold mineralization in the district is known to be associated with them.

\section{Conclusion}

The method of WofE is applied to obtain gold potential map based on geological, structural, and remote sensing data or maps, and also, 107 known gold mineralized locations in West Java. These exploratory maps are integrated to produce the final predictive mineral potential map. The result of $\mathrm{Au}$ potential map indicates that about $9902 \mathrm{~km}^{2}(21.62 \%)$ of the province as favourable zones. It predicts correctly $74(92.5 \%)$ of the 80 training data and predicts correctly $26(96.35 \%)$ of the 27 validation data. Moreover, the result of Au prospectively map indicates that about $3649 \mathrm{~km}^{2}(7.96 \%)$ of research area is low potential, $2844.75 \mathrm{~km}^{2}$ (6.21\%) is moderate potential and 2907 (6.35\%) is high potential zones. Bayah Dome is the highest potential zone, mineralization are associated with major NE-SW and NW-SE lineaments, the intersection zones between lineaments, and also characterized by minor N-S lineament and the lithologies of Bayah Dome is dominated by the intrusive intermediate, extrusive intermediate lava/poymict/pyroclastic, sandstone, breccias and claystone- shale which the ranges of age are between PleistoceneEocene. Potential areas of gold occurrences 
in research area is associated with NE-SW and NW-SE structure/lineaments, dominated surrounding the Tertiary extrusive volcanic rock and intrusive rock and hosted in Miocene to Pleistocene lithology rock unit The major prospective target areas for future exploration are located in southern mountain of research area like Ciemas, Garut, Cianjur, Tasikmalaya, and Bayha Dome is located western of SundaBanda arc. The small prospective target areas for future exploration are located in Bogor zone, Purwakarta and Pandeglang (Honjie Igneous Complex). These mineralization zones are also confirmed following field checking or visit of the study area. These target areas desirably include the variety of mineralization elements. This research shows that the method of WoE is an effective technique for the exploration and evaluation of regional-scale mineral deposits.

\section{Acknowledgements}

I would like to express my gratitude to the ASEAN University Network/Southeast Asia Engineering Education Development Network (AUN/SEED-NET) and Japanese International Cooperation Agency (JICA) providing me to study 'Master Degree' at Gadjah Mada University in Indonesia.

\section{References}

Alzwar, M., Akbar, N., and Bachri, S. (1992) Systematic geological map. International Journal of Remote Sensing, 21, pp. Indonesia, quadrangle Graut 1208-6 and Pameungpeuk 12083, scale 1: 100.000, Geological Research and Development Center, Bandung.

Basuki, N.I., Prihatmoko, S., and Suparka, E. (2012) Gold mineralization systems in Southern Mountain Range, West Java. Proceedings of Banda and Eastern Sunda Arcs 2012 MGEI Annual Convention 26-27 November 2012, Malang, East Java, Indonesia.

Bonham-Carter, G., Wright, D., and Agterberg, D. (1989) Weights of evidence modeling with GIS: A new approach to mapping mineral deposits. Geological Survey Canada Paper, 899: 171-183.
Carranza, E.J.M. (2002) Geologicallyconstrained Mineral Potential Mapping. PhD Thesis, Delft University of Technology, The Netherlands, 480p.

Carranza, E.J.M. (2003) Practical Exercise: Weight of Evidence Modeling for Mineral Potential Mapping. MREE Elective Module 9, 29pp.

Claproth, R. (1989) Petrology and Geochemistry of Volcanic Rocks from Ungaran, Central Java, Indonesia. Doctor of Philosophy Thesis, Department of Geology, University of Wollongong.

Idrus, A., Fadlin, Putri, R.I. and Hatmanda, M. (2013) Styles and Characteristics of Precious and Base Metal Mineralization at the Southern Part of West Java Region, Indonesia, The 5th AUN/SEED-Net Regional Conference on Geological Engineering 15-16 January 2013, Kuala Lumpur, Malaysia.

Marcoux, E., and Milési, J.P. (1994) Epithermal gold depositsin West Java, Indonesia: geology, age and crustal sources: in van Leeuwen, T.M., Hedenquuist, J.W., James, L.P., and Dow, J.A.S., eds., Mineral deposits in Indonesia, Discoveries of the Past 25 years: Journal of Geochemical Exploration, v. 50, pp. 393408.

Martodjojo, S., 1984, Evolusi Cekungan Bogor, Jawa Barat, Doctoral Dissertation, Department of Geology, Institut Teknologi Bandung, Bandung, 355p.

Milési, J.P., Marcoux, E., Nehlig, P., Sunarya, Y., Sukandar, A., and Felenc, J. (1994) Cirotan, West Java, Indonesia: a 1.7 Ma hybrid epithermal Au-Ag-Sn-W deposit. Economic Geology 89: 227- 245.

Milési, J.P., Marcoux, E., Sitrous, T., Simandjuntak, M., Leroy, J., and Baily L. (1999) a Pliocene supergene-enriched epithermal AuAg-(Mn) deposit. Mineral deposita 34: 131149.

Setijadji, L.D., Kajino, S., Imai, A., and Watanabe, K. (2006) Cenozoic island arc magmatism in Java Island (Sunda Arc, Indonesia): Clues on relationships between geodynamics of volcanic centers and ore mineralization. Resource Geology

Smyth, H. R, Hall, R., Hamilton, P.J., and Kinny, 
P. (2005) East Java: Cenozoic basins, volcanoes and ancient basement. Jakarta Proceedings, Indonesian Petroleum Association Annual Convention, 30th, pp. 251-266.

Suparka, E., Aziz, M., Abdullah, C.I., and Suparka, 2007. Mineralization of $\mathrm{Cu}-\mathrm{Au}$ porphyry deposits in Cihurip and Surrounding area, Garut Regency, West Java. Joint Convention The $36^{\text {th }}$ IAGI Annual Convention and Exhibition, Bali.

Syafrizal, Indriati, T., Heriawan, M.N., Hede, A., N., H., Hutabarat, Y., and Saing, S., (2011) Base-metal and gold mineralization in Jampang Complex, Cigaru Local Mine, West Java, Indonesia, Proceedings of the 1st Asia Africa Mineral Resources Conference 2011, Fukuoka, Japan.

Soeria-Atmadja, R. Maury, R. C., Bellon, H.,
Pringgoprawiro, H., Polves, M. and Priadi, B. (1994) Tertiary magmatic belts in Java. Journal of Southeast Asian Earth Science 9: 13-27. Subandrio, A.S, and Basuki, N.I. (2010) Alteration and vein textures associated with gold mineralization at the Bunikasih Area, Pangalengan, West Java, Jurnal Geologi Indonesia, v. 5(4), pp. 247-261.

Utoyo, H. (2007) Alteration and mineralization of ancient caldera in Cupunagara, Subang, West Java. Proceedings Joint Convention Bali 2007, The 32nd HAGI, The 36th IAGI, And The 29th IATMI Annual Conference And Exhibition.

van Bemmelen, R.W. (1949) The Geology of Indonesia. V.F.A. Govermment. Printing office. The Hague, 732p. 